\title{
Educação Intercultural e suas Ambivalências com o Estranho. Um Estudo Sobre a Representação Social do Negro no Livro Didático
}

\author{
Miguel Melo Ifadireól ; Tais Oliveira de Souza ${ }^{2}$; Érika de Sá Marinho Albuquerque ${ }^{3}$; \\ Maria do Socorro Cordeiro de Sousa ${ }^{4}$
}

\begin{abstract}
Resumo: O presente artigo é fruto dos trabalhos de leitura, pesquisas de campo e ações de extensão universitária que se enraizaram nas reuniões do Laboratório Interdisciplinar de Estudos da Violência (LIEV/ UNILEÃO) e nos encontros do Núcleo de Estudos em Gênero, Raça, Organizações e Sustentabilidade (NEGROS/ UPE), bem como, emergiu da necessidade de preparo de aulas e material didático para facilitar o ensino e as práticas pedagógicas para as disciplinas: Educação do Campo e Educação Intercultural no curso de Pedagogia da Faculdade de Ciências Humanas do Sertão Central (FACHUSC/ Salgueiro-PE. O objetivo da presente investigação está fundamentado na tentativa de destacar a contribuição que o material escolar pode, por um lado, dar à educação intercultural; e por outro lado, acentuar os nuances em que o racismo e o preconceito direcionados ao negro podem contribuir com a representação negativa destes na sociedade. A questão problema deste estudo concentra-se na investigação do material didático e paradidático do ensino infantil e fundamental selecionados e utilizados em uma escola pública do município de Verdejante, no Sertão Central Pernambucano. A metodologia utilizada é fruto da abordagem qualitativa, revisão bibliográfica e método de procedimento de análise documental com uso da abordagem crítica dos discursos. A fundamentação teórica especifica se deu a partir da teoria da ideologia de John Thompson (1995), da teoria da Mestiçagem de Kabengele Munanga (2008), da teoria da Pedagogia Intercultural de Georg Auerheimer (2005), da teoria da Estranheza na Escola de Franz Pöggeler (2004; 2003), dos Estudos Africanos de Achillie Mbembe (2014) e da filosofia da ancestralidade de David Oliveira (2007; 2003). Os achados nos permitem concluir que a educação intercultural satisfaz em plenitude os quesitos do respeito à dignidade da pessoa humana, da educação para a liberdade, da educação para a autonomia e da educação inclusiva e do pertencimento.
\end{abstract}

Palavras-chave: Educação Intercultural e Estranheza. Discriminação e Racismo. Material Didático. Representação Social do Negro.

\section{Intercultural Education and its Ambivalences with the Strange. A Study on the Social Representation of Black in the Didactic book}

\begin{abstract}
This article is the result of reading, field research and university extension activities that were rooted in the meetings of the Interdisciplinary Laboratory of Violence Studies (LIEV / UNILEÃO) and in the meetings of the Nucleus of Studies in Gender, Race, Organizations and Sustainability (NEGROS / UPE), as well as emerged from the need to prepare classes and didactic material to facilitate teaching and pedagogical practices for the disciplines: Field Education and Intercultural Education in the Pedagogy course of the Faculty of Human Sciences of the Central Sertão FACHUSC / Salgueiro-PE. The objective of the present investigation is based on the attempt to highlight the contribution that school

\footnotetext{
${ }^{1}$ Doutor em Sociologia (UFPE). Professor do Mestrado Profissional em Ensino em Saúde do Centro Universitário Dr. Leão Sampaio (UNILEÃO). Professor Assistente da Universidade de Pernambuco (UPE). Doutor em Sociologia pelo Programa de Pós-Graduação em Sociologia da Universidade Federal de Pernambuco. Professor-colaborador do curso de Pedagogia da Faculdade de Ciências Humanas do Sertão Central (FACHUSC). Pesquisador-líder do Laboratório Interdisciplinar em Estudos da Violência no Centro Universitário Dr. Leão Sampaio (LIEV-UNILEÃO). Pesquisador-líder do Núcleo de Estudos em Gênero, Raça, Organizações e Sustentabilidade (NEGROS) da Universidade de Pernambuco (UPE). Correio Eletrônico: crioulo.miguelangelo.melo@ gmail.com

${ }^{2}$ Graduação-Licenciatura em Pedagogia pela Faculdade de Ciências Humanas do Sertão Central (FACHUSC). Professora do Sistema de Ensino da Cidade de Verdejante/ PE. Correio Eletrônico: taisytalo@gmail.com

${ }^{3}$ Doutoranda pelo Programa de Pós-Graduação em Letras da Universidade do Estado do Rio Grande do Norte. Mestre em Direito pela Universidade Católica de Pernambuco. Professora do curso de Direito da Faculdade São Francisco da Paraíba (FASP). Especialista em Direito Processual Civil pela Universidade Católica de Pernambuco. E-mail. Erika-albuquerque@hotmail.com

${ }^{4}$ Doutoranda em Letras pelo Programa de Pós-Graduação em Letras (UERN). Mestra em Ensino pelo Programa de Pós-Graduação em Ensino (UERN). Professora temporária do curso de Pedagogia e Letras da Faculdade de Ciências Humanas do Sertão Central (FACHUSC). Correio Eletrônico: corrinhacordeiro@gmail.com
} 
material can give to intercultural education, on the one hand, and on the other, to emphasize the nuances in which targeted racism and prejudice can contribute to their negative representation in society. The problem issue in this study focuses on the investigation of the didactic and paradidático material of the infantile and fundamental education selected and used in a public school of the municipality of Verdejante, in the Sertão Central Pernambucano. The methodology used is the result of the qualitative approach, bibliographic review and method of documental analysis procedure using the critical approach of the discourses. The theoretical basis for this work is based on John Thompson's theory of ideology (1995), Kabengele Munanga's Theory of Mestizaje (2008), Georg Auerheimer's Theory of Intercultural Pedagogy (2005), Franz's School Oddity theory Pöggeler (2004, 2003), Achillie Mbembe African Studies (2014) and David Oliveira's philosophy of ancestry $(2007,2003)$. The findings allow us to conclude that intercultural education fully satisfies the requirements of respect for the dignity of the human person, education for freedom, education for autonomy and inclusive education and belonging.

Keywords: Intercultural and Strange Education. Discrimination and Racism. Courseware. Black Social Representation.

\title{
Considerações Iniciais
}

\begin{abstract}
"O negro prevalece sendo representado unicamente por uma lógica que o coloca sempre na mesma condição de seus antepassados escravizados e dificilmente pelas situações diversas que aparecem na sociedade contemporânea" (OLIVEIRA, 2000, p. 170 apud SILVA, 2008).
\end{abstract}

O confronto com o estranho é parte indispensável do hodierno discurso sociopolítico das sociedades internacionais, bem como nas regionais, tendo em vista que este é o alicerce que move o atual escopo e objetivos deste artigo, uma vez que este nos leva a refletir sobre $O$ que poderia querer um currículo, negro? O tema pesquisado da ênfase a discriminação racial, uma vez que esta atinge os sujeitos negros na escola, da mesma forma como ocorre na sociedade. O presente artigo é fruto dos trabalhos de leitura, pesquisas de campo e ações de extensão universitária que se enraizaram nas reuniões do Laboratório Interdisciplinar de Estudos da Violência (LIEV/ UNILEÃO) e nos encontros do Núcleo de Estudos em Gênero, Raça, Organizações e Sustentabilidade (NEGROS/ UPE), bem como, emergiu da necessidade de preparo de aulas e material didático para facilitar o ensino e as práticas pedagógicas para as disciplinas: Educação do Campo e Educação Intercultural no curso de Pedagogia da Faculdade de Ciências Humanas do Sertão Central (FACHUSC). Neste contexto pedagógico, evidenciou-se a justificativa do presente trabalho, principalmente, no contexto de preparo de aulas e material didático para facilitar o ensino e as práticas pedagógicas para as disciplinas: Educação do Campo (2018.1) e Educação Intercultural (2018.2) no curso de Pedagogia da referida IES, localizada em Salgueiro/PE. Neste contexto, se foi percebido a ausência de estudos específicos - trabalhos de conclusão de curso, sejam de graduação, especialização ou até mesmo pós-graduação strictu senso - sobre material didático, currículo, práticas pedagógicas interculturais nas escolas da região do Sertão Central de Pernambuco.

De modo que o presente estudo objetivou investigar, a partir das contribuições teóricas da abordagem da Educação Intercultural, as ambivalências com o Estranho, ou seja, como o Negro é representado socialmente nos livros didáticos de ensino infantil e fundamental. A questão problema deste estudo concentra-se na investigação do material didático e paradidático do ensino infantil e fundamental selecionados e utilizados em uma escola pública do município de Verdejante, no Sertão Central 
Pernambucano, uma vez que o foco está na análise de livros selecionados em relação ao conteúdo e currículo em seus aspectos interculturais da educação.

O objetivo da presente investigação está fundamentado na tentativa de destacar a contribuição que o material escolar pode, por um lado, dar à educação intercultural; e por outro lado, acentuar os nuances em que o racismo e o preconceito direcionados ao negro podem contribuir com a representação negativa destes na sociedade. Assim, percebe-se que o material escolar pode, por um lado, dar imensa contribuição à educação intercultural; e por outro lado, acentuar os nuances em que o racismo e o preconceito direcionados ao negro podem contribuir com a representação negativa destes na sociedade. Por conseguinte, busca o presente artigo ressaltar os sujeitos e as ressignificações destes sujeitos, os quais embebecidos pela etnofilosofia e educação intercultural, eminentemente decolonial, vêm recarregando acirrados debates (políticos e emocionais), movendo-se assim, entre os polos de tensão de uma "sociedade multicultural" "sociedade plural" ou "'sociedade intercultural" - que ainda promove nos currículos e livros didáticos escolares de ensino fundamental e médio o desprezo, a estranheza, a rotulação e o estigma com o "Outro desconhecido" (MELO, 2005).

No que compete a relevância do estudo em tela, esta se dá pela percepção de que é mais do que presente a necessidade de inserção e inclusão cidadã-participativa de indivíduos que são majoritariamente partes substanciais da estrutura étnico-cultural da sociedade brasileira.

Assim, antes de iniciar a pesquisa em tela, se foi de fundamental importância traçar o design de pesquisa, a metodologia e os métodos de procedimento a serem utilizados, tendo em vista que a metodologia utilizada tem como fundamento a abordagem qualitativa, revisão bibliográfica e método de procedimento de análise documental com uso da abordagem crítica dos discursos. A fundamentação teórica especifica se deu a partir da teoria da ideologia de John Thompson (1995), da teoria da Mestiçagem de Kabengele Munanga (2008), da teoria da Pedagogia Intercultural de Georg Auerheimer (2005), da teoria da Estranheza na Escola de Franz Pöggeler (2004; 2003), dos Estudos Africanos de Achillie Mbembe (2014) e da filosofia da ancestralidade de David Oliveira $(2007 ; 2003)$. Por conseguinte, cabe salientar que, também, foi feito análise dos livros Lourdes Carril (1997) intitulado "Em terras de negros", bem como do livro "História da Educação do Negro e Outras Histórias" lançado pelo UNESCO (2005). Acrescenta-se que ambos os livros são partes integrantes do acervo didático de uso geral e específico empregado no ensino infantil e fundamental da Escola Clementino Nogueira Verdejante-PE. Deste modo, ao iniciar as leituras críticas sobre o assunto em tela apercebemos que o conteúdo proposto, desde o projeto de pesquisa, revela um fenômeno de omissão, exclusão e rotulação do negro, uma vez que este é negativamente e socialmente muito mal representado nos livros escolares, nas propostas de ensino/aprendizagem, pelas práticas pedagógicas docentes e discentes, conforme buscaremos demonstrar ao longo do presente trabalho.

Este artigo, é elaborado na abordagem qualitativa, através de análise de casos a pesquisa foi realizada a partir da coleta de dados em livros didáticos utilizados pela turma de $6^{\circ}$ ano fundamental, bem como se foi feito análise dos livros de história do Pré-Escolar I e II da escola municipal Clementino Nogueira - durante os meses de agosto e outubro de 2019 -, os instrumentos utilizados para tal pesquisa foram os livros, através de anotações de dados em cadernetas de pesquisas, onde se foi a relação dos textos e das ilustrações presentes 
em cada livro, vendo a representação do negro em relação ao branco, onde todos dados dos livros selecionados foram registrados e organizados. Cada dado registrado foi dividido como componente curricular, número de cenas analisados no livro, qual a representação do negro nas cenas e qual a representação do branco. Onde mostra a veracidade de como o negro é visto de maneira desigual. Em relação os livros do pré-escolar foram analisados 05 livros, os mais trabalhados pela professora. Onde para análise consta; nome do livro; fase I ou II; representação do negro; representação do branco.

Acentua-se que este trabalho é limitado a seguir para uma discussão crítica de conceitos interculturais e antirracistas, uma vez que estas abordagens (especialmente os conceitos de educação intercultural) ainda ocupam uma posição de invisibilidade tanto no discurso de pesquisadores sobre o ensino, quanto nos discursos proferidos por pesquisadores da educação em geral. Deve-se notar, no entanto, que uma comparação das abordagens que serão feitas neste artigo, estas apenas farão sentido na medida em que diferenças fundamentais nas linhas de argumentação possam ser entendidas pelos leitores. Em geral, há também sobreposições entre as duas abordagens, em que uma separação estrita não é possível, uma vez que observamos com razão que as abordagens da pedagogia geral e tradicional, até então utilizadas, não podem lidar com o racismo e o preconceito em nossa hodierna sociedade, principalmente, no que se refere à pluralidade das posições e à diversidade de conceitos e sujeitos.

\section{As Ciências do Conhecimento e o Debate "Raciológico" Mundial - Alguns Apontamentos}

"[...] o negro era muito mais utilizado como objeto que como sujeito. A complexidade das culturas africanas não era abordada”. (PINTO, 1999 apud SILVA, 2008).

O debate com o racismo na forma de pesquisa não tem uma curta história no Brasil, em comparação com outras nações americanas e europeias, muito embora este debate apenas a partir da segunda metade do século XX, é que se foi intensificado por vozes do ativismo político negro, e apenas com a virada do século XX com o surgimento de específicos programas de pós-graduação strictu senso sobre Cultura e História Africana e Indígena, é que realmente, se deu a proliferação de estudos e pesquisas sobre o racismo no cotidiano brasileiro. Enquanto isso, numerosos estudos mostraram que padrões racistas de pensamento e estruturas são difundidos em nossa sociedade, e, portanto, um exame do assunto também é essencial para os educadores. Salienta-se que esta disputa é explicada pela manipulação descuidada de palavras de estigma e palavras de bandeira.

De acordo com o lema "Diga-me o que lhe parece estranho, e eu lhe direi quem você é!" (SCHÄFFTER 1991, p. 7), essa discussão leva a convulsões frenéticas, ambivalentes e contraditórios tanto no seio dos distintos movimentos sociais, quanto nos espaços políticos e acadêmicos, os quais vêm produzindo posicionamentos argumentativos e teóricos recheados de concepções xenofóbicas, lgbtfóbicas, misóginas e racistas (MELO, 2018; GOMES FILHO, 2017). Para a ciência da educação (pedagogia), a tarefa aqui é desenvolver serviços educacionais adequados que possam contribuir para a participação igualitária de todos os membros da sociedade - independentemente de sua origem, aparência e cultura. Além de um conhecimento profundo e refletido do fenômeno social do racismo, é igualmente necessário, do ponto de 
vista pedagógico, desenvolver medidas adequadas de prevenção e intervenção a fim de neutralizar as manifestações do racismo.

A pedagogia já desenvolveu diferentes conceitos para combater o racismo, muito embora, ainda existam claras abordagens e referenciais teóricas que apresentam nuances de racismo de forma indireta, subliminar ou tácita, no que diz respeito às prioridades temáticas, inventários metodológicos e objetivos formulados. (MELO; BANDEIRA, 2016, p. 215). A pedagogia intercultural, assim como a pedagogia antirracista, surge como resposta aos processos migratórios e de imigração, os quais tomaram forma avassaladora na Europa a partir dos anos 70 do século XX. Movida pelas novas epistemologias filosóficos, sociológicos, antropológicos, jurídicos e pedagógicos, ela (pedagogia intercultural) tomou forma, passando assim, a desenvolver novos conceitos destinados a abordar e combater o racismo; entretanto, seus fundamentos e posições teóricos ainda são pela abordagem tradicional e geral, amplamente criticados. (DEGLER, 2004).

No seio deste diapasão entre distintas ontologias e epistemologias teóricas, levantam-se as seguintes questões problemas: a) Quais são as oportunidades e os limites dos conceitos interculturais e antirracistas que podem ser desenvolvidos tanto na escola, quanto nos livros didáticos para combater o racismo? b) qual seria a contribuição da abordagem teórica da educação intercultural para a percepção das práticas de racismo e preconceito? c) finalmente, questiona-se se a promoção de políticas públicas educacionais com fulcro na etnofilosofia e/ou pedagogia intercultural poderiam ser capazes de combater os nuances do racismo e do preconceito nos livros de ensino não apenas no sistema de ensino infantil e fundamental, mas em todo o sistema de ensino brasileiro, seja escolar, seja universitário.

Neste sentido, salienta-se que a educação intercultural é um eficaz referencial teórico e tem plena capacidade de apontar novas possibilidades de desenvolvimento para o trabalho pedagógico, a partir da discussão crítica de ambas as vertentes teóricas. Aliás, além da análise crítica do nível teórico-conceitual da pedagogia intercultural e antirracista, esta abordagem também proporciona um olhar sobre (des)construtivista sobre as práticas pedagógicas tracionais que se põem na transversalidade de uma discussão realista do problema étnico-racial nas escolas e sistemas de ensino no Brasil. A fim de esclarecer a relevância da questão e da promoção de ações pedagógicas para a educação, percebe-se que um olhar sobre estudos críticos sobre o desenvolvimento e a disseminação dos atuais padrões racistas de pensamento e estruturas pedagógicas de ensino/aprendizagem no Brasil, é uma emergente necessidade, muito embora este não é o objetivo deste artigo, o qual já foi apresentado nas considerações iniciais do mesmo.

Por conseguinte, entende-se que para que se torne possível a promoção de uma avaliação sobre os conceitos existentes, é necessário, antes de tudo, analisar em detalhes o complexo fenômeno do racismo e, respectivamente, do preconceito, tendo em vista que se deseja aqui a promoção de uma consciência críticoreflexiva sobre o seu contexto pedagógico-político e cultural, o qual a nosso ver: é histórico e reproduz causas subjacentes. (LISBOA, IFADIREÓ, ALBUQUERQUE FILHO; SOUSA, 2018). Além de um olhar para a gênese, para definições selecionadas e esclarecimentos conceituais e demarcações, esta seção do trabalho enfocará alguns modelos psicológicos e sociológicos selecionados para a explicação do racismo. Com base 
nas conclusões da análise, será desenvolvido um conceito de trabalho que constitui um ponto de partida para a avaliação de conceitos interculturais e antirracistas.

Posteriormente, as estratégias de ação intercultural e antirracista serão apresentadas e analisadas criticamente, uma vez que fundamentamos a nossa análise na educação intercultural como modelo de reflexão da pluralidade e diversidade de possibilidades para se tratar temas como: cultura, educação, didática, currículo, teorias pedagógicas e a diferenças, bem como todos os outros conceitos e categorias que estão fundamentados nestes. (LISBOA, IFADIREÓ, ALBUQUERQUE FILHO; SOUSA, 2018). Corroborando com esta perspectiva, Cláudia Regina de Paula (2010) ao estudar as "Histórias da Educação do Negro e Outras Histórias" recupera a definição do Dicionário Aurélio eletrônico século XXI, um dos mais renomados dicionários da Língua Portuguesa, o qual conceitua a categoria branco como "Branco; Adj. da cor de neve, do leite, da cal; alvo; cândido; claro; transparente; translúcido; diz do indivíduo de raça branca; Fig. Sem máscula; inocente; puro; ingênua" (AURÉLIO,1999: p.102).

Ao referenciar o conceito de negro e, respectivamente da cor negra, a autora apresenta as seguintes definições presentes no vernáculo de língua portuguesa: "Negra: S. f. mulher de cor preta; escrava. Ou Negro: Adj. De cor preta; sujo; encardido; preto; muito triste; lúgubre; melancólico; funesto; maldito; sinistro; perverso" (IBID. p.452-453). A este respeito, Miguel Melo e João Bandeira (2016), entendem que:

Dessa feita, tais teorias racistas colocavam o negro em um polo enquanto povo "bárbaro, primitivo e pagão"; e no outro surgia o discurso que legitimava o branco como povo "civilizado, culto e cristão". Decerto, é necessário destacar que os conceitos em voga sofreram modificações ao longo do tempo, acompanhando assim, o desenvolvimento sócio-político que construiu a trajetória da humanidade. (MELO; BANDEIRA, 2016, p. 230).

Para muitas situações a cor negra é logo comparada a sujeira isto está nítido no dicionário, o qual é um dos recursos mais trabalhados em nossas escolas, ou seja a questão não se resume só a um problema centrado nos livros, ou nas escolas, mais também, na rua, em lojas, na mídia digital, televisiva, ou seja, a temática do preconceito e do racismo é uma questão cultural que tendenciosamente, é o motor transmissor e propagador da xenofobia em relação ao negro e a cultura proveniente deste. Além disso, no entanto, os conceitos explicados pelo emérito dicionário brasileiro, amplamente utilizado nas escolas nacionais, proliferam e reproduzem o rótulo que não apenas nega, bem como refuta a ideia da interculturalidade, os quais serão nas próximas sessões analisados criticamente. Na prática, o foco está na abjeção ao sujeito negro, atrelando-se a este uma cor, que está recheada de negatividade, historicamente e socialmente construída. Por conseguinte, a habilidade e sensibilidade pedagógica intercultural nos leva a questionar a proliferação e defesa deste modo de pensar o negro nos livros escolares e didáticas de ensino.

Acreditamos que é emergente repensar as representações sociais do negro, do índio, dos quilombolas, bem como todos os povos e comunidades tracionais - como por exemplo, os religiosos e as religiões de matrizes indígenas, africanas e afrodescendentes - dentro da esfera de ensino e de produção didática para o ensino e para a educação. Pois, a educação é um espectrum de sentido abstrato, e deve ser repensada em toda a sua conjuntura, ou seja, é necessário ressignificar desde as ações extracurriculares, curriculares até desaguar na educação continuada com fulcro na interculturalidade. (AUERHEIMER, 2005). 
Em contraste, ainda é predominante a discussão sobre uma pedagogia antirracista, a qual encontra a sua ancoragem teórica em ultrapassados métodos e programas, propagadores de uma sensível e em parte enganosa, política pública de educação inclusiva, a qual só lembra do negro, do índio, do quilombola em datas festivas e específicas, as quais findam por distanciarem-se do centro do interesse e da relevância da própria educação.

As consequências e desafios dos conceitos pedagógicos da educação intercultural estão na percepção e, respectivamente, na desconstrução decolonial - político-ideológica - da educação tradicional e na luta e no enfrentamento contra o racismo, uma vez que é deste embate teórico que resultam dos pontos fortes e fracos (convergentes e divergentes) dos conceitos pré-existentes no seio das distintas abordagens e teorias da educação brasileira. (CASTRO, 2000). Antes de nos debruçarmos detalhadamente o fenômeno do racismo nos livros didáticos estudados, a partir da método de análise documental e de revisão bibliográfica aos livros didáticos utilizados na escola visitada no município pernambucano de Verdejante, localizado no Sertão Central do Estado de Pernambuco, emerge a questão problema de saber se, ou em que medida, o racismo difundido no Brasil tem influência no ambiente escolar como um todo. (LISBOA, IFADIREÓ, ALBUQUERQUE FILHO; SOUSA, 2018). Se olharmos para as investigações e estudos sobre este assunto, fica claro que uma ampla disseminação de padrões racistas de pensamento, bem como a violência racista tanto na academia, quanto nas teorias produzidas e utilizadas nas escolas brasileiras, as quais podem ser facilmente detectadas. Para poder responder à questão das oportunidades e limitações dos conceitos antirracistas e interculturais contra o racismo, é importante antes de tudo analisar os fenómenos do racismo. (MILES, 1989).

$\mathrm{Na}$ discussão científica proferida no Brasil sobre o racismo, no entanto, encontramos posicionamentos e respostas diferentes, as quais podem ser decisivas para a proliferação e a embasamento com relação aos pontos de vista teóricos elementares, que dificultam a percepção do fenômeno no cotidiano escolar como um todo. Portanto, parece apropriado iluminar o fenômeno a partir de diferentes perspectivas. Assim, partimos da certeza de que, em primeiro lugar, é necessário compreender que o termo racismo advém da errônea concepção de "raça"; e em segundo lugar, é importante delinear que a história colonial brasileira teve influência fundamental na propagação ideológica da superioridade/ inferioridade de indígenas e negros em relação ao branco, emergindo assim, as significações teóricas que espraiaram-se na propagação do racismo nos livros escolares e materiais didáticos amplamente utilizados nas escolas brasileiras. (CARNEIRO, 1988). Antes que qualquer definição do mesmo deva ser usada na análise do racismo, é necessário e sensato, primeiro, entrar em mais detalhes sobre o desenvolvimento histórico dos conceitos de raça e racismo e seus conceitos associados.

Deve-se enfatizar que a ciência já refutou a existência de uma "raça" humana desde meados do século XX. No entanto, o termo tem desempenhado historicamente um papel crucial na classificação e avaliação de culturas ou comunidades culturais subordinadas, dominadas e inferiorizada por outra cultura ou comunidade cultural tida como hegemônica, padrão, civilizada e/ou superior. Finalmente, fazendo uso da reflexão promovida pela educação intercultural chegamos a constatação de que alguns dos padrões racistas ainda presentes nas atuais ciências produtoras do conhecimento, não devem ser entendidos apenas em seu 
contexto histórico e cultural-social, mas sim, na conjuntura racional de como a perspectiva histórica em análise pode influenciar as ideologias da presente sociedade.

\section{Experiências e Ressignificações em torno da Educação Intercultural à Luz da Etnofilosofia}

Aqui, em primeiro lugar, a determinação conceitual da autoconfiança aparece no contexto do próprio campo de ação pedagógica (ALAVI, 2016), principalmente, na esfera da discussão pedagógica comparada. Neste sentido, recorrendo as experiências e ressignificações da presente investigação, fazendo uso das contemporâneas discussões na Europa, países que vivenciam ondas de imigração nas quatro últimas décadas -, verifica-se que a temática da convivência em uma sociedade intercultural, apensar de ser um tema complexo, é reflexo dos atuais processos de migração. Fato é que a Imigração (ato de entrar em um outro Estado), bem como a Emigração (ato de sair de seu Estado) são normais na história da humanidade, uma vez que sempre houve movimentos migratórios - sejam eles imigratórios, sejam eles emigratórios - e, portanto, estes processos sempre foram vistos como estranhos (ALAVI, 2016; LENZEN, 1991). Muito embora, a estranheza e o estranho da realidade em Alemã, respectivamente, europeia não corresponde, a realidade brasileira. (LISBOA, IFADIREÓ, ALBUQUERQUE FILHO; SOUSA, 2018).

Pois, as religiosidades ou as práticas religiosas de matrizes africanas e afro-brasileiras, fazem parte da formação cultural e étnica brasileira, o que não justifica na atualidade a estranheza em relação à Cosmovisão Africana - seus saberes e dizeres ancestrais - tanto nos currículos escolares, quanto nos livros didáticos. O foco primordial deste artigo objetiva ressignificar a questão de como a sociedade brasileira (pedagogia e currículos escolares) vem na atualidade, promovendo ações pedagógicas que, ainda, tratam com estranheza no contexto de própria cultura didática e curricular a ancestralidade africana. Para compreensão deste diapasão pedagógico e filosófico, recorreu-se, por um lado, as atuais abordagens da educação intercultural (AUERHEIMER, 2005; PÖGGELER, 2004; 2003); por outro lado, buscou-se fundamentação teórico-epistemológica na etnofilosofia sustentáculos sobre outras possíveis estratégias de compreender os processos eurocêntricos de exclusão, rotulação e estigmatização do Outro Africano dentro dos currículos e livros didáticos brasileiros.

A este respeito, ressaltam Adilbênia Machado (2012) e David Oliveira (2003) que a filosofia africana tem importância fundamental na reedificação do processo filosófico mundial, tendo em vista que esta filosofia, ao buscar compreender e ressignificar o pensamento social e cultural não hegemônico, consegue permitir que caminhemos para às margens do saber, ou seja, que busquemos conhecer os "saberes esquecidos" - advindos "dela" (Ancestralidade) e "dele" (Encantamento) - e renegados pelo pensamento "tradicional" europeu (OLIVEIRA, 2007). Assim, a filosofia africana consegue (des)hegemonizar, principalmente, ao possibilitar que caminhemos e aprendamos com as "encruzilhadas" (OLIVEIRA, 2007), tendo em vista que "a ancestralidade e o encantamento complementam-se, desejam-se, [...] onde estes são plurais e diversos.". (MACHADO, 2012, p. 23).

Aos olhos críticos da Educação Intercultural e da Etnofilosofia, constata-se que o Outro (estranho) e a Cultura Africana e/o Afrodescendente (estranheza) receberam, e ainda, recebem - desde o modelo 
ocidental de educação jesuíta-cartesiana e suas distintas relações de poder e dominação - rótulos e estigmas, os quais desvalorizam e deslegitimam os sentidos para os saberes pedagógicos e filosóficos que fujam ao projeto civilizatório, predominantemente ocidental (MBEMBE, 2014). Assim, através das categorias de pertencimento e (des)confiança, às quais uma vez postas e sobrepostas em contraste, espraiam-se no imaginário coletivo, produzindo assim, representações sociais que findam por produzir conhecimentos que negam a atribuição de sentidos, ao que coletivamente é posto e imposto como estranho, não apenas afetando o Outro, mas fazendo que este acredite que sua estranheza é real, por isso, "ele se torna merecedor de tal estranheza, onde a ausência de afeto, afeta o estrangeiro, e em primeiro lugar o afeto negativo" (LANDMANN, 1999, p.180).

No entanto, a criticidade ao pensamento ocidental, permite o despertar para o encantado, tornando o estranho consciente e capaz de se libertar da situação que o oprime e o domina, seja de forma abrupta, seja de forma secreta (LANDMANN, 1999, p.183). Nos dois polos da ameaça e do fascínio (SCHÄFFTER, 1991, p.7) ou do "horror allieni" e do "amor alieni" (LAUTMANN, 1999, p.183), funda-se a peculiar ambivalência do estranho. Assim, na exploração da uniformidade e da diferença, construiu-se este artigo, o qual buscará debater a emersão de abordagens pedagógicas e filosóficas, capazes de deslegitimar o "constructo cultural" que tentou manter a estranheza, como uma "experiência desafiadora da identidade" (SCHÄFFTER, 1991, p. 12) dos afro-brasileiros.

O embaraço, portanto, só surge racionalmente em um modo de relacionamento no contexto de uma situação sociocultural e historicamente condicionada e mutável (MBEMBE, 2014), perceptível a partir das contemporâneas abordagens epistemológicas. Por conseguinte, acrescenta-se que estas abordagens promovem não apenas o encontro entre os dois modelos de razão e relação, mas impõem a crítica reflexão e o encontro do estranho com o hegemônico modelo civilizatório e de conhecimento que o subjugava e hostilizava. Assim, percebe-se que é a partir deste encontro epistemológico que se elevam discursos e ênfases em prol das diferenças, por um lado, aos processos de demarcação e exclusão - à inimizade (BREITLING; REESE-SCHÄFER, 1994), por outro, no reconhecimento de semelhanças aos processos de compreensão e ao desenvolvimento de "técnicas culturais de lidar e compreender a estranheza". (SCHÄFFTER, 1991).

\section{Sobre as Ambivalências com o Estranho Nos Livros Didáticos e para Didáticos Infantis sob o Foco da Pedagogia Intercultural}

A revisão de literatura sobre os estudos prévios referentes ao tema em estudo, remete-nos ao pioneiro estudo de Dante Moreira Leite (1950, apud NEGRÃO, 1987) como primeiro trabalho na seara da educação sobre a produção de rótulos e estigmas sociais em livros didáticos nacionais, os quais segundo Paulo Baptista da Silva (2008) foram reforçados pelas pesquisas desenvolvidas por Sérgio Buarque de Holanda (1957, apud ROSEMBERG, 1985) e Waldemiro Bazzanella (1957, apud ROSEMBERG, 1985). Estes pioneiros estudos foram publicizados em meados do século XX, os quais já apresentavam a realidade de que tanto o racismo, quanto o preconceito étnico-racial eram manifestados nos livros didáticos nacionais de "forma velada ou implícita" e, frequentemente traziam mensagens sublimares da submissão e do atraso cultural destes dois 
grupos étnico-raciais, contribuíam assim, para a construção e representação do estigma social do negro e do índio como indivíduos inferiores em relação ao branco, uma vez que o preconceito direcionado a estes sujeitos era "raramente apresentado de forma aberta, com hostilidades diretas ou defesa da "inferioridade natural" dos negros". (SILVA, 2008, p. 26).

Como será mostrado em seção posterior - dos resultados e das discussões - as ideias raciais ou ideias gerais de "Outros" (culturas, nações, povos) se desenvolveram a partir de processos de categorização. Com a ajuda de categorias que consistem em propriedades reais e atribuídas, uma distinção pode ser feita entre o próprio grupo e outro grupo. Franz Pöggeler (2004) também observa que as formas de representação ou representação do Outro evoluíram a partir de movimentos migratórios determinados pela produção, pelo comércio e pela guerra e pelo concomitante encontro de indivíduos e grupos. As formas historicamente condicionadas de representação oferecem uma explicação para o comportamento e a aparência do Outro (estranho). Quando exatamente as ideias raciais da história começaram, é difícil avaliar e também é controverso. Da mesma forma, a palavra história do termo "raça" não é uniformemente datada na literatura.

No entanto, pode-se verificar que a "raça" remonta às formas da linguagem românica no século XIII. No espanhol "raza", o português "raça" ou o francês "race". (MILES, 1989). Do velho francês derivado da palavra inglesa "race" no século XVI, até que o termo foi introduzido pela primeira vez no idioma dos Estados de língua alemã o termo em finais do século XVIII, principalmente, nos Estados da Prússia, Hamburgo, Berlim e Bremen. (PÖGGELER, 2003). Fato: temos a certeza de que o desenvolvimento histórico do termo "raça" e seu conteúdo ideológico, desagua no iluminismo, e se espalha no esclarecimento alemão e no renascimento italiano e britânico. (MILES, 1989). Assim, ressalta-se o fato de que este foco genealógico sobre a origem e evolução do racismo, não é em momento algum, objeto do presente trabalho, uma vez que não se busca aqui teorizar ou promover uma revisão bibliográfica sobre o racismo, esta já foi muito discutido por autores, tais como Hannah Arendt, ao apontar que "se o racismo não existisse, o imperialismo o teria inventado" (1979, p. 183-184). Um exemplo deste invento, que a ciência chama de racismo, temos o alastramento de verdades acadêmicas que manifestaram-se e acompanharam o desenvolvimento do espírito da época, a saber, a frenologia e a fisionomia, entre outras especulações e experimentos teóricos que dominaram o cenário e os salões do conhecimento Europeu contribuíram para a propagação do racismo e do preconceito em relação ao negro (LÜCK/ STÜTZEL 2009).

Neste sentido, ressalta-se que tanto a frenologia - ciência interpretativa da saúde do crânio - quanto a fisionomia - ciência interpretativa da face humana - surgiram em finais do século XVIII, e passaram a influenciar e a espraiarem-se no seio de outras ciências humanas (sociais) e naturais (médicas e exatas), tais como o Direito, a Pedagogia, a Política, a Biologia, a Economia, a Teologia de matriz judaico-cristã entre outras. Os seus defensores acentuavam que por meio de unidades corporais e mentais, uma vez medidas e observadas poderia ser possível detectar doenças, problemas de sociabilidade, comportamentos criminosos e desviantes, doenças e taras mentais e dificuldades de aprendizagem. Até que a genética fosse capaz de decodificar os mecanismos de herança, tendo em vista que os cientistas europeus acreditaram e continuaram tentando conectar e explicar a evolução da história e da natureza humana com o conceito de raça. (CONRAD, 1975). 
Presenciamos na primeira metade do século XIX, por um lado, a publicização de mitos e verdades "absolutas e universais" sobre o termo raça em quase todos os estudos de ciência e pseudociência. Historiadores, políticos, médicos, padres e biólogos, assim como narradores-viajantes, lidavam com "raças", e traziam a estas narrativas seus juízos de valores que findavam por influenciar a conjuntura do pensamento racial dos "homens da siencia" brasileiros (SCHWARCZ, 1993). Em contraste com o conceito de uso no século 18, o conceito de raça não era mais utilizado para distinguir as raças humanas de diferentes raças: características individuais de propriedades eram como um personagem masculino e feminino, um grupo familiar, uma cultura regional, classe social, ou mesmo um grupo profissional descrito com o conceito de raça. Cada vez mais, a ideia de "raça" tornava-se uma categoria socialmente construída e usada para justificar e legitimar as ações de conquista, escravidão, catequese, massacre, genocídio e aniquilação cultural, religiosa e cultural, conquista de povos e culturas "primitivas, pagãs e não-cristãs" com fulcro na moralidade e salvação cristã.

Assim, a crescente popularidade das ciências (abordagens teóricas) frenológicas e fisiológicas, as quais combinavam discursos legitimadores do racismo, uniam-se a outros discursos em defesa de características naturais e socioculturais. (HASENBALG, 1996). Por outro lado, observa-se que foi na segunda metade do século XIX - com o desenvolvimento e aprimoramento das expansões mercantis imperialistas das metrópoles europeias em relação as colônias (africanas, americanas, asiáticas e oceânicas) - foi que a teoria da evolução realmente passou a "levar a cabo" a ideia de "raça", uma vez que seus defensores passavam a argumentar que cada raça poderia ser classificada na escada evolucionária, surgindo assim novas abordagens teóricas, tais como a teoria do embranquecimento e a da mestiçagem (MUNANGA, 2008), como salientam “[...] as confrontações críticas contra o racismo originárias da promoção do discurso de brancura são provavelmente tão antigas como a razão da disparidade racial que se baseia na própria brancura" (LÜCK/ STÜTZEL 2009, p. 336). Corroborando com esta perspectiva, Eske Wollrad (2005, p. 21) acirra o debate ao apontar que:

O termo brancura - que enseja no racismo ou em práticas de violência racial vivenciadas durante e/ou posteriormente ao período colonial - refere-se a sociedades racialmente estruturadas em um sistema de hegemonia racial ancorada por privilégios e pela busca de uma identidade específica e estática que se diferencie o mínimo possível do estabelecido pela realidade social, material e implicações econômicas. (IDEM., 2005, p. 21).

Henrique Cunha Júnior (2012), em sua crítica decolonial sobre as implicações econômicas, políticas e sociais da propagação de ideias e/ou pressuposições teóricas sobre o embranquecimento e mestiçagem no Brasil, assevera que a história econômica brasileira nunca buscou olhar para o negro e, respetivamente, para o índio com outro olhar que não enxergasse a força bruta para o trabalho escravo, marginalizando-os, negando-os o direito a ter Direito, propagando assim, uma "pseudo" inferioridade racial que se reproduz ainda hoje no cenário escolar. Padrões teórico-reflexivos que deram sustentáculo para o aprimoramento do pensamento racista na modernidade, ou seja, foi na Antiguidade e no Medievo que as raízes do embasamento 
teórico da ideologia racial se iniciam, fomentam-se e propagam-se, principalmente, nos tempos do Iluminismo, diga-se também, do Esclarecimento e do Renascimento.

Neste sentido, o filósofo e historiador francês Christian Delacampagne também vê a época do Iluminismo como a origem das formas modernas de racismo. Embora ele ressalte que o racismo já existia antes, desde a sociedade helênica, bem como na medieval. Pois, Delacampagne enfatiza que as crenças raciais só foram remodeladas, teoricamente substanciadas e sistematizadas nessa época, uma vez que ainda formam a base teórica das modernas ciências, entre estas, destacam-se as da natureza, que proliferam muitas das modernas concepções racistas oriundas da belle epoche. (DELACAMPAGNE, 1983). A este processo acirram-se os debates que permearam a transição do século XVIII para o XIX já dava ideias pronunciadas sobre "raças" e sua classificação hierárquica para os estudiosos. A concepção de uma "raça" de ordem superior (branca, clara) e de uma "raça" inferior (escura) determinou a visão de mundo de muitos cientistas e pensadores e foi ainda mais disseminada por numerosas publicações na virada do século XIX para o século $\mathrm{XX}$, muito embora apenas na segunda metade do século XX é que se iniciam as discussões e abordagens teóricas críticas ao pensamento dominante da época.

É neste período, que as discussões providas da primeira metade do século XX, desconstituem a força dos argumentos propagadores do conceito de raça, muito embora esta tendência europeia, no Brasil ainda não viessem sendo observada, pelo contrário, somava-se a perspectiva da "raça", o aspecto do embranquecimento racial e a miscigenação racial como certeza e verdade da evolução ontogênica do povo brasileiro. (LISBOA, IFADIREÓ, ALBUQUERQUE FILHO; SOUSA, 2018). Corroborando com esta perspectiva de menosprezo as "raças" não ocidentais e brancas, recortamos dois trechos que demonstram as inconsistências e desarranjos estereotipados da intelligentsia brasileira, em finais do século XIX e inícios do século XX, em defesa do embranquecimento e na condenação a miscigenação:

É preciso ser completamente ignorante em coisas de antropologia e etnologia para desconhecer o duplo fenômeno da persistência dos caracteres fundamentais das raças, por um lado, e, por outro lado, o fenômeno de cruzamento de todas elas, sempre que se acham em contato. O desaparecimento total do índio, do negro e do mestiço poderia ocorrer, apenas, se toda a miscigenação futura incluir um parceiro exatamente claro (senão branco) [...]. (ROMERO, 1914, p. 401 apud MUNANGA, 2008, p. 50).

[...] o povo brasileiro, como hoje se nos apresenta, se não constitui uma só raça compacta e distinta, tem elementos para acentuar-se com força e tornar-se um ascendente original nos tempos futuros. Talvez tenhamos ainda de repensar na América um grande destino histórico-cultural. (ROMERO, 1975, p. 16 apud MUNANGA, 2008, p. 50).

Logo, estas novas abordagens teóricas, oriundas das mais distintas ciências humanas e sociais, bem como as exatas e da natureza produzidas no Brasil, permaneciam não apenas fazendo uso do conceito "raça" para distinguir as distintas etnias humanas, bem como ressignificavam as teorias europeias, "abrasileirandoas", uma vez que assim, o conceito tornava-se uma categoria social unicamente ideológica que passava a ser utilizada, por um lado, apenas como motor de políticas sociais excludentes e taxativas, que negavam o reconhecimento da condição humana; e por outro lado, insistiam em utilizá-la como explicação da ação social legitimadora do racismo e do preconceito em relação a fusão da cultura branca (europeia) com a indígenas e 
negras, taxadas como "espécies incapazes" (RODRIGUES, 1957, p. 90). Seguindo este raciocínio Miguel Melo e João Bandeira (2016) entonam que:

\begin{abstract}
Constata-se que novas abordagens e métodos diferentes estão se solidificando nas mais diferentes ciências epistemológicas - filosofia, psicologia, sociologia, direito, pedagogia, antropologia, biologia, história, linguística etc - e que a sociedade brasileira a exemplo de outras sociedades, está aprendendo a lidar com o "Outro" e que "ser diferente" é não é apenas um direito, mas uma garantia constitucional. Dentro desta linha de raciocínio percebemos que a derrubada e transformação nas relações de poder fundadas em concepções racistas advindas de elementos constitutivos de uma pseudomaioria "branca ocidental e cristã" enquanto reflexo de dominação - étnico, cultural e religiosa - caminham para fazer parte apenas de nossa história. (MELO; BANDEIRA, 2016, p. 216).
\end{abstract}

Dentro deste contexto, verifica-se que Nina Rodrigues busca ao mesmo tempo legitimar e influenciar a institucionalização de uma legislação excludente, segregadora e racista, a qual iria, a partir de caracteres eugenistas e fisiológicos, instituir um direito penal diferenciado em matéria étnico-racial. A este respeito Munanga (2008) apresenta fortes críticas ao médico maranhense, ao satirizar e perguntar o seguinte: O que teria acontecido se as elites brasileiras tivessem conseguido institucionalizar a dinâmica do direito penal diferenciado-racial conforme proposto por Nina Rodrigues?, uma vez que para o op. cit. autor, o projeto civilizatório e racista de Nina Rodrigues, nada mais representava do que a simbolização do pensamento predominante na elite brasileira, principalmente, porque para Nina Rodrigues e para as nossas elites racistas, era marcante a determinação estereotipada acerca de "características raciais inatas" de negros e índios (MUNANGA, 2008, p. 50). Pois, este comportamento inato seria impulsionador do comportamento a social e da cultura primitiva destes povos (SCHWARCZ, 1993). Por isso, estes deveriam ter majoradas as penas restritivas ao direito de liberdade, tanto por conta pelos legisladores, quanto pelas ações e postulações das autoridades policiais:

A elite brasileira, preocupada com a construção de uma unidade nacional, de uma identidade nacional, via está ameaçada pela pluralidade étnico-racial. A mestiçagem era para ela uma ponte para o destino final: o branqueamento do povo brasileiro. Mas entre o modelo, a estratégia política montada e a realidade empírica, existe uma certa margem, que não pode ser negligenciada nas considerações socio antropológicas da realidade racial brasileira. (IDEM., p. 105-106).

Consequentemente, a ordem jurídica interna deveria desenvolver um rígido jus puniendi ao status quo de negros e índios, atribuindo a estes uma responsabilidade penal atenuada, a qual seria justificada pela existência de leis diferenciadas entre estes sujeitos-objetos e os sujeitos-cidadãos da raça branca (superior). Neste contexto de movimentação pró-hegemonia, contra hegemônica, difusão, assimilação e refutação aos ideais de dominação e "(a)normalidades" teórica em torno das concepções de raça, miscigenação e embranquecimento, proferidos da virada do século XIX até fins da primeira metade do século XX, percebese que acirrados debates foram travados tanto na sociedade, quanto na academia; até que em finais do século $\mathrm{XX}$, os movimentos sociais surgidos como forma de contestação a dominação da cultura do WHASP - branca, anglo-saxônica, heterossexual, masculina e protestante - se espalham na Europa e América do Norte pós- 
segunda Guerra, trazendo assim, novas perspectivas teóricas que aderem se põem na contramão da deslegitimação e negação do discurso "majoritário" como aponta Carlos Hasenbalg ao trazer estes novos discursos:

\begin{abstract}
Dois parecem ser os pontos centrais em torno dos quais se estabelecem as semelhanças entre o Brasil e os outros países latino-americanos. O primeiro deles é o embranquecimento, entendido como um projeto nacional implementado por meio da miscigenação seletiva e políticas de povoamento e imigração europeia. O segundo é a concepção desenvolvida pelas elites políticas e intelectuais a respeito de seus próprios países, supostamente caracterizados pela harmonia e tolerância racial e ausência de preconceito e discriminação racial. (HASENBALG., 1996, p. 236).
\end{abstract}

Assim, percebemos que tanto na Europa quanto no Brasil, a virada do século, XIX para o XX, apresentou no pós guerras - primeira e segunda guerra - grandes transformações epistemológicas, a saber: ao término Primeira Guerra Mundial solidificam-se e espraiam-se assustadoramente as políticas racistas na Europa, tendo em vista que estas vem a legitimar a perseguição, o massacre semita na Europa até a realização da solução final, quando os Judeus tornaram-se a ponta do Iceberg da discriminação racial através dos genocídios em campos de concentração. Corroborando com esta visão, Robert Milles (1989) já nos chamara atenção para o fato de que o termo racismo:

[...] apareceu pela primeira vez na década de 1930 e, portanto, tem uma história muito mais curta do que o conceito de raça, embora o racismo já existisse há muito tempo. Antes disso, outros termos como "ódio racial" foram usados na literatura norteamericana e por mim para fundamentar a ideia da ação pros motivos raciais [...]. Em primeiro lugar minada [...] o crescimento constante da evidência científica, a idéia de "raça" como uma subdivisão ligada, separado e definido natural da espécie humana [...]. Por outro lado, havia a resposta à ascensão do fascismo alemão. (IDEM, 1989, p. 97).

Por conseguinte, ao revisar a literatura norte-americana e a europeia, encontramos várias citações Hamid Reza Yousefi e Ina Brown (2012), John Hope Franklin e Alfred Moss Junior (2009) e Ivonne Maggie (1991) entre outros, - que nos remetem a Robert Milles (1989), os quais teriam durante as décadas de 1930 e 1940, servido de referências a numerosas publicações na Europa e na América, indo de encontro a tendência do Nacional Socialismo Alemão e dos países do Eicho, os quais propagavam os ideias do conceito de "raça" surgidos no contexto pós Primeira Guerra. (GOLDHAGEN, 1998).

Com o término da Segunda Guerra Mundial, as já ultrapassadas abordagens biológicas do evolucionismo social de Darwin, perderam espaço para o determinismo biológico e sua "moderna" genética eugênica, as quais também foram abandonadas, desencadeando assim, a desaprovação ao antigo e predominante conceito de "raça" (OOSTERHUIS, 2002; DUPPONT, 2002; LEPENIES, 1988). Além disso, é importante destacar que os "homens da sciencia" - medicina, biologia, psiquiatria e psicologia - foram determinantes para a realização de experimentos propagadores e executores da política de perseguição nazista durante todo o Terceiro Reich do Nacional Socialismo Alemão, os quais não ousaram em medir esforços "naturalizar", justificar e legitimar suas ações extremistas da época. (GRAU, 2002; RÖNN, 2002). 
Neste contexto, salienta-se a preocupação das Organizações Internacionais Regionais e Globais - tais como a UNESCO, ONU e OEA - que uma vez acionadas pelo ativismo militante feminista e negro, ou melhor, movimento negro e movimento negro feminista que denunciava o "discurso ideológico em livros didáticos" (SILVA, 2008, p. 35), passou a negociar com os Estados-membros e Estados-partes, bem como com terceiros Estados, uma "série de negociações e ações governamentais visando à eliminação" (IDEM, p. 35), de políticas de exclusão e de violação aos direitos humanos (dignidade da pessoa humana) motiva pelos discursos e práticas étnico-raciais, de gênero e religiosas, tendo em vista que "uma das principais reivindicações do movimento negro" (IDEM, p. 35) brasileiro fundava-se na expressa proibição e alteração de toda e qualquer manifestação de preconceito e racismo em livros e materiais didáticos. (GUIMARÃES, 2002 apud SILVA, 2008, p. 35).

Assim, desde a Carta das Nações Unidas - ratificada em 1945 - e que em seu artigo $1^{\circ}$ trazia a prerrogativa da obrigação de buscar a realização dos direitos humanos e liberdades fundamentais para todos, sem distinção de raça, sexo, idioma ou religião, muita coisa foi acontecendo e modificando o cenário mundial em relação ao desenvolvimento de políticas públicas internacionais de combate ao racismo, intolerância religiosa, racismo religioso e xenofobia, tendo em vista que os movimentos sociais foram fundamentais para o emplacamento destas políticas supranacionais, a saber: a) Declaração da ONU sobre a Eliminação de Todas as Formas de Discriminação Racial em 1963; b) Convenção Internacional sobre a Eliminação de Todas as Formas de Discriminação Racial em 1965; c) primeira Conferência Mundial de Combate ao Racismo e à Discriminação Racial foi realizada em Genebra em 1978; d) segunda Conferência Mundial de Combate ao Racismo e Discriminação Racial, realizada em Genebra em 1983; e) Conferência Mundial contra o Racismo, Discriminação Racial, Xenofobia e Intolerância Relacionada na Durban/África do Sul em 2001; f) Conferência Mundial contra o Racismo, Discriminação Racial, Xenofobia e Intolerância Relacionada na Durban/África do Sul em 2009.

Fato: estas abordagens histórico-descritivas nos permitiram demonstrar os mecanismos dicotômicos que podem ser utilizados pela ciência, seja para refutar discursos racistas, seja para propagar e legitimar estes discursos e suas "anomalias", os quais permitiram que pré-conceitos fossem formados e propagados mundialmente, trazendo nos livros didáticos vários juízos de valores perpassados desde então, conforme serão apresentadas na interpretação dos dados (resultados e discussões) da pesquisa, a saber: a) a preguiça do índio; b) a incapacidade cognitiva do negro; c) o negro como medroso; d) o branco como corajoso; e) a ingenuidade do índio; f) a propagação da superioridade racial e intelectual da raça branca sobre as outras raças inferiores (negra, vermelha e amarela) que determinaram a visão de muito de muitos cientistas, filósofos, escritores, poetas, musicistas, pedagogos, juristas entre outros profissionais através de inúmeras publicações.

\section{Análise de Livros Didáticos e Pradidáticos do Sexto Ano Fundamental: Um Olhar Acerca da Interculturalidade}

A análise foi feita em livros do didáticos e paradidáticos do $6^{\circ}$ ano fundamental - português, matemática, história, geografia e ciências - todos já na edição 4 revisada, atualizada e publicada em 2012, 
bem como em cinco livros didáticos e paradidáticos do ensino infantil da fase I e II. Neste contexto, percebeuse a marca de estratégias discursivas e ideológicas, as quais de forma tendenciosa exaltam de forma um tanto simplificada, a representação social do negro e a condição secundária na sociedade. Assim, a interpretação dos dados coletados nos induzem a percepção de que a representação do negro, nestes livros, ainda é cerceada pela demonstração de inferioridade étnico-racial, uma vez que os resultados demonstrados a seguir, demonstram que: a) a maioria das ilustrações apresentam o negro em quantidade bem inferior aos brancos e, quando este é trazido em pauta, é simbolizado em posição sem destaque ou com pouco prestígio social; b) se foi detectado várias situações de preconceito velado, em que práticas de racismo são apresentadas com mensagens ideológicas de submissão e de dominação em relação aos sujeitos brancos; e c) a elevação de juízos valorativos em relação a cultura, saberes, religiosidade e práticas sociais africanas, afrodescendentes e quilombolas claramente expostas nos livros didáticos e paradidáticos consultados.

Quadro 1- Quantidade em que o Negro em relação ao branco aparece nos livros e quais suas representações.

\begin{tabular}{|c|c|c|c|}
\hline Livro didático & $\begin{array}{l}\text { Números de } \\
\text { figuras } \\
\text { analisadas }\end{array}$ & Representação do negro & $\begin{array}{c}\text { Representação do } \\
\text { branco }\end{array}$ \\
\hline Português & 10 & $\begin{array}{l}\text { Aluno minoria; } \\
\text { tela em La Greouillere (1881), } \\
\text { nenhum negro sentado à mesa; } \\
\text { Turma da Mônica todos brancos; } \\
\text { Princesas brancas na maioria, e } \\
\text { uma única princesa negra; } \\
\text { negro representado como } \\
\text { medroso; } \\
\text { trabalhador de roça; moça negra } \\
\text { ajudando menino de rua, } \\
\end{array}$ & $\begin{array}{l}\text { Aluno branco como maioria; } \\
\text { Menina branca corajosa; } \\
\text { Sem brancos na roça; } \\
\text { Menino de rua branco; } \\
\text { Princesa como leite na } \\
\text { maioria; } \\
\text { Princesa negra como } \\
\text { minoria. }\end{array}$ \\
\hline Matemática & 14 & $\begin{array}{l}\text { Negra fora da brincadeira; } \\
\text { Negra convida amigos por carta; } \\
\text { Negra com calculadora para } \\
\text { calcular; } \\
\text { Maioria das cenas os negros como } \\
\text { minoria; } \\
\text { Ilustração de uma eleição cabos } \\
\text { eleitorais todos brancos; } \\
\text { negra como empregada servindo } \\
\text { crianças; } \\
\text { Vendedor de tinta negro; } \\
\text { Nenhum bebe negro. } \\
\end{array}$ & $\begin{array}{l}\text { Criança branca brincando; } \\
\text { - Criança branca sem } \\
\text { calculadora; } \\
\text { Brancos como maioria } \\
\text { Vendedor de vinho branco; } \\
\text { Todos bebês brancos; } \\
\text { Nenhuma empregada } \\
\text { branca. }\end{array}$ \\
\hline História & $\begin{array}{l}3 \\
\text { Mais estudos da } \\
\text { história em si no } \\
\text { geral } \\
\end{array}$ & $\begin{array}{l}\text { Valorização da família do negro; } \\
\text { História dos povos indígenas; } \\
\text { Ilustração dos trabalhos indígenas }\end{array}$ & $\begin{array}{l}\text { Família de brancos para } \\
\text { comparar; }\end{array}$ \\
\hline Geografia & $\begin{array}{c}2 \\
\text { Trabalha mais } \\
\text { espaço, terra lugares } \\
\text { e mapas. } \\
\end{array}$ & Trabalhador de mandioca negro; & Turista brancos; \\
\hline Ciências & 7 & $\begin{array}{l}\text { Negro abrindo capitulo; } \\
\text { Sala de aula } 1 \text { negro } \\
\text { Família negra unida; } \\
\text { Família branca comida saudável e } \\
\text { Gari negro. }\end{array}$ & $\begin{array}{l}\text { Crianças brancas no parque; } \\
\text { Sala de aula muitos brancos; } \\
\text { Homem branco doando sofá. }\end{array}$ \\
\hline
\end{tabular}

Fonte: Levantamento direto - análise documental (2018) 
A tabela acima nos permite tecer as seguintes considerações: a) o negro nos livros didáticos é representado de forma geral por ilustrações, exemplos, textos e figuras que revelam o mesmo cotidiano de abandono, exclusão, criminalização, miséria e desemprego, ausência de status e prestígio social; b) a marcante ausência do negro em sala de aula é ressignificada nos livros didáticos; c) as profissões e os papéis sociais de prestígio social são dedicados aos brancos, enquanto que aos negros são trazidos como profissionais de profissões secundárias; d) o corpo negro e a sexualidade negra da mulata do carnaval, do jogador de futebol ou dos musicistas do samba são rotulados nos exemplos de interação ou democracia racial; d) Também foi perceptível que estas representações racistas não são trabalhadas na sala de aula durante o uso do livro didático de maneira de desconstrução do racismo, muito pelo contrário estas cenas são passadas por despercebidas pelos professores.

Quadro 2- As fabulas mais trabalhados na sala de aula do pré-escolar fase I e II, a representação do negro e do branco no livro.

\begin{tabular}{|c|c|c|c|}
\hline Livro analisado & Fase & $\begin{array}{c}\text { Representação do } \\
\text { negro }\end{array}$ & $\begin{array}{c}\text { Representação do } \\
\text { branco }\end{array}$ \\
\hline$O$ patinho feio & I & $\begin{array}{l}\text { Sem representação do } \\
\text { negro, mostra um } \\
\text { desprezo em relação ao } \\
\text { pato por ele ser diferente } \\
\text { dos outros. } \\
\end{array}$ & $\begin{array}{l}\text { Sem representantes } \\
\text { brancos ou negros, } \\
\text { mostra a desvalorização } \\
\text { de um animal por ser } \\
\text { diferente dos demais. }\end{array}$ \\
\hline Cachinhos dourados & I E II & $\begin{array}{lll}\text { Nenhum } & \text { negro } & \text { na } \\
\text { história. } & & \end{array}$ & $\begin{array}{l}\text { A representação do } \\
\text { branco nesta história é } \\
\text { bem clara pois a } \\
\text { personagem principal } \\
\text { loira dos cabelos logos } \\
\text { de olhos claros e cabelos } \\
\text { loiros. }\end{array}$ \\
\hline A princesa e o sapo & II & $\begin{array}{l}\text { So aparece como negra a } \\
\text { cozinheira do castelo. }\end{array}$ & $\begin{array}{l}\text { A princesa tem } \\
\text { característica de } \\
\text { perfeição cabelos louros, } \\
\text { longos pele clara e mora } \\
\text { em um castelo cheio de } \\
\text { luxos, a personagem } \\
\text { aparece em toda história } \\
\text { feliz e cassa com um } \\
\text { belo príncipe com } \\
\text { característica parecidas } \\
\text { com a dela. }\end{array}$ \\
\hline A ovelha negra & I & $\begin{array}{l}\text { A ovelha nesta fabula é } \\
\text { preta. }\end{array}$ & $\begin{array}{l}\text { Mostra uma família } \\
\text { composta por um pai } \\
\text { uma mãe e um filho, mas } \\
\text { o interesse maior desta } \\
\text { família é na lã da ovelha, } \\
\text { uma vez que eles } \\
\text { almejam um casaco de } \\
\text { pele de ovelha. }\end{array}$ \\
\hline O gato de botas & I E II & $\begin{array}{llr}\text { Nesta história } & \text { não } \\
\text { aparece } & \text { nenhum negro, } \\
\text { nem mesmo } & \text { os } \\
\text { trabalhadores } \\
\text { encontrados durante as } \\
\text { aventuras do gato de } \\
\text { botas. }\end{array}$ & $\begin{array}{l}\text { Todos os personagens } \\
\text { são brancos nem mesmo } \\
\text { o gato tem pelo negro. }\end{array}$ \\
\hline
\end{tabular}

Fonte: Levantamento direto - análise documental (2018) 
Nesta análise foi possível observar que os livros mais usados nas turmas do pré-escolar I e II são livros paradidáticos, como fábulas, onde: a) nenhuma das história retrata a figura negra como protagonista social; b) as falas de atores das fábulas não trazem a superação de estigmas étnico-raciais, tampouco desconstroem os discursos racistas em relação ao negro; c) inexistem fábulas que desconstruam a historicidade da inferioridade étnico-racial, tampouco desfaçam o mito da democracia racial; d) a presença de conceitos ideológicos é marcada por ações e práticas nos livros paradidáticos que tendem a promover um sistema de ideias recheados por ilusões falsas, verdades universais e exaltação da beleza ocidental em príncipes e princesas nestas fábulas.

Neste sentido, recorremos à teoria da ideologia com fulcro em John Thompson (1995) para interpretarmos e compreendermos os nuances da problemática étnico-racial e o modus operandi pelos quais a ideologia racial é subliminarmente, ainda, marcante nos livros didáticos e paradidáticos consultados, a saber: a) legitimação, b) dissimulação, c) unificação, d) fragmentação e e) reificação. Em primeiro lugar, a legitimação ideológica do racismo se dá na pouca atenção que a gestão escolar, seja ela no sistema de ensino público, seja no privado, a operacionalização do racismo e na propagação dos estigmas sociais da inferioridade racial do negro, tendo em vista que os simbolismos da diferença e da desigualdade econômicas são sobrepostos como determinantes, e não a questão étnico-racial. Assim, a desigualdade e a ausência de visibilidade na representação positiva do negro são tanto justificadas, quanto legitimadas pelo discurso dominante.

Em seguida, observa-se o critério da dissimulação ideológica, a qual segundo o autor, se dá pela tentativa simbólica de desviar a atenção do problema em si, para outro. Desviando, negando, ocultando os processos sociais desqualificadores e promotores das diferenças. Os discursos dissimuladores trazem na atualidade, por exemplo, a questão do "mimimi do movimento negro, tudo agora é racismo". Observa-se, por um lado, nesta estratégia ideologia, as tentativas de deslocar o problema, e os sentidos correspondentes a estes problemas; por outro lado, a prática do eufemismo, que tenta desvirtuar o problema ou a culpa do racismo institucional da escola, do sistema de ensino, do material didático e dos próprios professores.

Em terceiro lugar, aponta-se para a estratégia ideológica da unificação, uma vez que esta busca a promoção do falso sentimento de unicidade, de identificação coletiva, e do esquecimento aos erros do passado, em prol de um futuro promissor e garantidor de uma igualdade e equidade para todos, onde o que importa é a funcionalidade do sistema e, a paciência, para a minimização das diferenças. O estado deverá garantir a supremacia do coletivo sobre o individual. Por conseguinte, percebeu-se a prática da ideologia da fragmentação, ou seja, a tentativa de convencimento social de que a existência de subgrupos e diversidades de identidades poderia ameaçar a garantia da ordem e da paz social, ou seja, a funcionalidade do sistema, por um lado, deveria focar em dividir para conquistar; por outro lado, a divisão facilitaria qualquer tentativa de rebelião ou de contraposição ao sistema, a ordem, a moralidade e aos juízos de valores estabelecidos como corretos.

E finalmente, a estratégia ideológica da reificação, a qual busca em sua essência destituir a capacidade da memória ou identidade coletiva pela coisificação do próprio homem e de sua história. Acontecimentos, narrativas, a tradição, os costumes e a religiosidade transmitida pela oralidade são rotuladas 
como atemporais, fora de moda a partir da imposição de uma cultura de massas, sem memória e ao mesmo tempo artificial ou superficial, visando apenas a produção de massa para o consumo. De modo que quem está fora deste circulo consumidor é retratado como fracassado ou a social. Intenta-se aqui refletir a partir do material didático e currículo escolar como o negro é representado dentro do ambiente escolar, bem como no material de ensino, seja no ensino infantil ou fundamental. Fatos que se tornaram perceptíveis, a partir da pesquisa, e os resultados indicam que: a) não só na escola, mais em todo o cotidiano das interações sociais, o negro é tratado com inferioridade do que pessoas de pele cor branca; b) ausência de visibilidade em situações de sucesso profissional e credibilidade social do negro em relação ao branco; c) nas relações de sociabilidade, seja no universo escolar (ensino fundamental e infantil), seja na territorialidade acadêmica nas universidades, percebe-se que não é fácil para o aluno negro, muito menos para os professores negros tornarem-se visíveis e ressignificarem-se enquanto sujeitos dentro de um universo que nega ou que dificulta a sua ascensão profissional; e d) o racismo contra o negro no âmbito escolar é parte integrante do cotidiano, isto começa desde o convívio com os colegas, chegada e permanência na escola, ausência de professores negros ou de profissionais negros em posições de gestão ou de destaque na escola, acessibilidade e aquisição de material escolar e, por fim, a representação social do negro no livro didático.

A pesquisa trouxe os seguintes achados sobre a representação do Negro nos livros didáticos e paradidáticos, a saber: a) a questão da discriminação racial está claramente nos livros didáticos e paradidáticos, os quais ressignificam e introduzem novas formas de preconceito e de racismo; b) livros didáticos e paradidáticos, enquanto meio de facilitação do conhecimento para o professor, também são instrumentos propagadores do racismo, do machismo, da intolerância religiosa, da lgbtfobia e da misoginia entre outras categorias de preconceito; c) a representação negativa em relação ao negro, bem como, a outros grupos vulneráveis vítimas de falas, pensamentos e pronunciamentos racistas que foram ludicamente e pedagogicamente representados e identificados no contexto escolar.

\section{Conclusões}

Ao longo deste estudo que fez uso de diferentes métodos de investigação social na seara da educação e do ensino - revisão de literatura, pesquisa de campo e uso do método de análise documental - chegamos aos seguintes achados e considerações finais: em primeiro lugar, elucidamos que mudanças de paradigmas na ordem político e jurídica internacional desencadearam processos sociais que influenciaram a abertura de novas conjunturas histórico-sociais e políticas que propiciaram o desenvolvimento da abordagem teórica que ficou conhecida como educação intercultural, a qual ressignifica o olhar para o Outro (estranho, esquisito), percebendo-o não como um problema, mas como um ganho sociocultural para a sociedade receptora.

Em segundo lugar, ressalta-se que devido à variedade e a diversidade postulatória de princípios, conceitos, objetivos e discursos críticos presentes no fundamento da educação intercultural, este complexo teórico finda por influenciar a reformulação e ressignificação das estruturas do sistema de ensino (formação 
e capacitação profissional, material didático de ensino e currículo) e nas políticas públicas de educação das sociedades e dos estados da contemporaneidade.

Demonstrou-se que o objetivo da educação e formação profissional com fulcro na concepção de interculturalidade é, portanto, para as políticas públicas de inclusão e de governança participativa, por outro lado, o meio para se atingir os fins democráticos, reconhecido pela Organização das Nações Unidas para a Educação, a Ciência e a Cultura (UNESCO) como um dos melhores instrumentos de promoção de habilidades participativas e inclusivas, por exemplo, o conhecimento e a desvantagem estrutural, a sensibilidade a possíveis diferenças, a capacidade de mudar a perspectiva da supremacia ou universalidade cultural em relação à culturas particulares. Dentro desta visão, acentua-se, aqui, a importância de se apresentar uma concepção pedagógica que priorize e que advogue em nome da igualdade de direitos e oportunidades sociais, independentemente da origem e da atitude de aceitação, do respeito pela especialidade e do reconhecimento das diversidades presentes na nossa sociedade, a saber, do Município de Verdejante/ PE. Essa concepção de educação intercultural torna-se indispensável na complexa e heterogênea sociedade.

Vimos que a educação intercultural encontrou seu nascedouro na educação de adultos no contexto Europeu e Norte-americano, ao buscarem meios e mecanismos para inserção dos imigrantes, atentando-se para as novas necessidades da sociedade globalizada. Logo, o termo "intercultural", mesmo não sendo claramente definido pelas distintas ciências humanas, sociais e da natureza, a sua emergência e praticidade é indiscutível, independente do campo e da tensão da incorporação de suas práticas de ensino, a sua abordagem teórica produz um novo modelo de reivindicação normativa, que por si só, finda por produzir novos conceitos, concepções e estratégias de ensino eficaz para promover, no estudo em tela, uma nova representação social de sujeitos excluídos e estigmatizados como os negros e a cultura africana e afrodescendente no Brasil, seja na sociedade, seja na escola como um todo.

Quinto, os resultados e achados da pesquisa nos permitem assegurar que a pedagogia intercultural no sistema de ensino brasileiro, deve assumir uma posição de destaque na busca para promoção de uma coexistência e interação social com dignidade entre as diferentes culturas, promovendo assim, uma cultura da paz de caráter eminentemente inclusivo e com habilidade para impedir que mal-entendidos, preconceitos e racismos permaneçam sendo praticados no ambiente escolar como um todo, seja no currículo, seja nas práticas de ensino ou até mesmo na formação por livros didáticos e/ou paradidáticos.

Por conseguinte, percebe-se que a educação intercultural satisfaz em plenitude os quesitos do respeito à dignidade da pessoa humana, da educação para a liberdade, da educação para a autonomia e da educação inclusiva e do pertencimento, mecanismos principiológicos estes que são capazes de minimizar e reduzir drasticamente as diferenças que levam à exclusão, à discriminação, ao racismo e ao racismo religioso, à misoginia, ao chauvinismo, à lgbtfobia e ao antissemitismo entre outras formas de estranhamento e exclusão social.

Em sétimo lugar, ressalta-se que através da educação intercultural é possível trabalhar e permear não apenas a escola - pedagogicamente contra atitudes, opiniões, pré-conceitos e estigmatizações de estranhamento sobre os Outros -, mas a sociedade como um todo, e que é possível minimizar e reduzir a zero as ambivalências de estranhamento que reproduzem o modelo antigo de educação com fulcro no 
redimensionamento de estratégias e novas formas de pensar que sejam necessárias para a solidificação de uma sociedade não apenas da tolerância, mas da aceitabilidade ao Outro-Ser, independentemente da sua diferença.

Finalmente, conclui-se que o que vem sendo executado em sala de aula, não legitima as diferentes e variáveis de vozes dentro das próprias diferenças na territorialidade escolar em sentido abstrato, uma vez que as direções do pensamento filosófico cartesiano predominantes na pedagogia geral é eminentemente ocidental, a qual exclui a representação e a existência de Outras filosofias (filosofia africana, filosofia indígena, filosofia oriental entre outras) e respectivamente, de Outros modelos pedagógicos de ensino que fujam ao padrão ideológico estabelecido como universal, talvez, por receio de que estes Outros pensamentos, possam se transformar em mecanismos de libertação e de integração direta na ordem prática e política de um Estado que sobrevive dos antigo modelo de sociabilidade.

Neste contexto, percebe-se que tanto a etnofilosofia (filosofia africana/ filosofia indígena) como prática de educação intercultural seria um novo aroma espiritual hábil para despertar em nós brasileiros, a África e o Brasil Indígena nos tempos modernos. Por um lado, ele [pedagogia intercultural] continua a luta pela descolonização, estendendo-o para o campo da consciência libertadora; e por outro lado, ela [pedagogia intercultural] fornece os anéis que representam a conquista de uma nova identidade cultural e uma nova autoconsciência mais emancipada e mais igualitária, com respeito a diversidade e as diferenças.

\section{Referências}

ALAVI, Bettina. Plädoyer für neue geschichtsdidaktische Überlegungen bezüglich der Methodik eines inklusiven Geschichtsunterrichts, S. 102-140. In: Bettina Alavi; Martin Lücke (Hrsg.): Geschichtsunterricht ohne Verlierer!? Inklusion als Herausforderung der Geschichtsdidaktik. Schwalbach.: Wochenschau 2016.

ARENDT, Hannah. The origins of totalitarianism. New York: HBJ Book, 1979.

AUERHEIMER, Georg. Einführung in die Interkulturelle Pädagogik. Stuttgart - Darmstadt: Wissenchaftliche Buchgesellschaft Verlag, 2005.

AURÉLIO, Buarque de Holanda Ferreira. Dicionário Aurélio eletrônico século XXI. [S.I.]: Nova Fronteira, 1999. Versão 3.0 - 1 CD-ROM.

BAZZANELLA, Waldemiro. Valores e estereótipos em livros de leitura. Boletim do Centro Brasileiro de Pesquisas Educacionais, Rio de Janeiro, v. 2, n. 4. mar. 1957.

BORGES, E MEDEIROS, C.A. e D’ADESKY, J, Racismo, preconceito e intolerância. São Paulo: atual,2002.

BREITLING, Petra; REESE-SCHÄFER, Walter (Hg.). Universalismus, Nationalismus und die neue Einheit der Deutschen. Frankfurt am Main: Suhrkamp Verlag, 1994.

CARNEIRO, Maria Luiza Tucci. Preconceito racial: Portugal e Brasil Colônia. São Paulo: Brasiliense, 1988. 
CARRIL, Lourdes. Terras de negros e herança de quilombos. Editora Scipione.1997

CASTRO, Hebe M. Mattos de. Escravidão e cidadania no Brasil monárquico. Rio de Janeiro: Jorge Zahar, 2000. (Coleção Passo a Passo).

CONRAD, Robert. Os últimos anos da escravidão no Brasil. Rio de Janeiro: Editora Civilização Brasileira. 1975.

CUNHA JR, Henrrique. Quilombo: patrimônio histórico e cultural. In: Revista Espaço Acadêmico - Nº 129 - Fevereiro de 2012. Mensal - Ano XI. Pp. 158 - 167.

DEGLER, Carl N. Nem preto nem branco: escravidão e relações raciais no Brasil. Cad. Pagu, n. 23, p. 199228, 2004. [on-line]. (do original: DEGLER, Carl N. Nem preto, nem branco. Rio de Janeiro: Labor, 1976).

DELACAMPAGNE, Christian. L'Invention du racisme: antiquité et moyen age. Paris: Fayard, 1983.

DUPPONT, Marc. Biologische und psychologische Konzepte im Dritten Reich" zur Homosexualität, 189208. In: JELLONNEK, Burkhard; LAUTMANN, Rüdiger (Hrsg.). Nationalsozialistischer Terror gegen Homosexuelle. Verdrängt und ungesühnt. Paderborn - München - Wien - Zürich: Ferdinand Schöningh Verlag, 2002.

FRANKLIN, John Hope; MOSS JUNIOR, Alfred A. Von der Sklaverei zur Freiheit. Die Geschichte der Schwarzen in den USA. Erweiterte und aktualisierte Ausgabe. Berlin - New York - Amsterdam: Theodor Bayer-Eynck Verlag, 2009.

GOLDHAGEN, Daniel Jonah. Der eliminatorischen Antisemitismus im modernen Deutschland, p. 107164. In: GOLDHAGEN, Daniel Jonah. Hitlers willige Vollstrecker. Ganz gewöhliche Deutsche und der Holocaust. München - Amsterdam - Berlin: Siedler Verlag, 1998.

GOMES, Nilma Lino; SILVA, Petronilha Beatriz Gonçalves. $3^{a}$ Edição. Experiências étnico-culturais para a formação de professores Belo Horizonte: Autêntica editora, 2011 (Coleção Cultura Negra e Identidades).

GRAU, Günter. "Unschuldige Täter". Medizin als Vollstrecker der nationalsozialistischen Homosexuellenpolitik, 2009-236. In: JELLONNEK, Burkhard; LAUTMANN, Rüdiger (Hrsg.). Nationalsozialistischer Terror gegen Homosexuelle. Verdrängt und ungesühnt. Paderborn - München Wien - Zürich: Ferdinand Schöningh Verlag, 2002.

HASENBALG, Carlos. Entre o mito e os fatos: Racismo e relações raciais no Brasil. In: MAIO, M.C./ SANTOS, R. V. (Org.) Raça, ciência e sociedade. Rio de Janeiro: Fiocruz/ 1996.

HOLANDA, Sérgio Buarque de. Caminhos e fronteiras. Rio de Janeiro: Livraria José Olympio Editora, 1975 [1957].

LANDMANN, Michael. Das Fremde und die Entfremdung, S. 180-219. In: Heinz-Horst Schrey (Hrsg.). Entfremdung. Verlag Freies Gestesleben: Stuttgart, 1999.

LENZEN, Dieter. Multikulturalität als Monokultur, S. 147-157. In: Ottfried Schäffter (Hrsg.). Das Fremde. Erfahrungsmöglichkeiten zwischen Fazination und Bedrohung. Westdeutschland Verlag: Opladen 1991. 
LEPENIES, Wolf. Between litterature and Science: the rise of sociology. Cambridge: Cambridge University Press, 1988.

LISBOA, Emanoel Jackson; IFADIREÓ, Miguel Melo; ALBUQUERQUE FILHO, José Antônio de; SOUSA, Maria do Socorro Cordeiro de. Educação Intercultural e Integração Social: Uma Proposta Pedagógica para a Docência no Sistema de Ensino da Cidade de Parnamirim/PE. Id on Line Rev.Mult. Psic., 2018, vol.12, n.42, Supl. 1, p. 759-776. ISSN: 1981-1179.

LÜCK, Mitja Sabine/ STÜTZEL, Kevin. Zwischen Selbstreflexion und politischer Praxis: Weißsein in der antirassistischen Bildungsarbeit. In: MENDE, Janne/ MÜLLER, Stefan (Hg.): Emazipation in der politischen Bildung. Theorien - Konzepte - Möglichkeiten. Schwalbach am Taunus: Wochenschau, 2009.

MACHADO, Adilbenia. Filosofia africana e currículo: Aproximações. Revista Sul-Americana de Filosofia e Educação, Brasília, v. 0, n. 18, maio de 2012. Disponível em:

periodicos.unb.br/index.php/resafe/article/view/14990. Acesso em: 10. Jan. 2017.

MAGGIE, Ivonne. A ilusão do concreto: Análise do sistema de classificação racial no Brasil. Tese de titulação. Rio de Janeiro, UFRJ, 1991.

MBEMBE, Achillie. Crítica a razão negra. Tradução Marta Lança.3ª ed., Lisboa: Antígona Editores, 2014.

MELO, Miguel Ângelo Silva de; BANDEIRA, João Adolfo Ribeiro. Crítica aos estereótipos e ideias racistas no Brasil sob o prisma dos estudos Pós-coloniais. In: Revista Direito \& Práxis, Rio de Janeiro, Vol. 07, N. 15, 2016, p. 213-246.

MILES, Robert. Racism. London: Routledge, 1989.

MUNANGA, Kabengele. Rediscutindo a mestiçagem no Brasil. Identidade Nacional versus identidade negra. 3. Ed. Belo Horizonte: Autêntica, 2008.

NEGRÃO, E. V. A discriminação racial em livros didáticos e infanto-juvenis. Cadernos de Pesquisa, São Paulo, n. 63, p.86-87, nov. 1987.

OLIVEIRA, Marco Antônio de. O negro no ensino de história: temas e representações. Dissertação (Metrado em Educação), Universidade de São Paulo, 2000. APUD SILVA, Paulo Vinícios Baptista da. Racismo em Livros Didáticos: estudo sobre negros e brancos em livros de Língua Portuguesa. Belo Horizonte: Autêntica Editora, 2008 (Coleção Cultura Negra e Identidades).

OLIVEIRA, Eduardo David. Filosofia da Ancestralidade: corpo de mito na filosofia da educação brasileira. Curitiba: Editora Gráfica Popular, 2007.

$\overline{2003 .}$

Cosmovisão africana no Brasil: elementos para uma filosofia afrodescendente. Fortaleza: LCR,

OLIVEIRA, J.B. et. Política da política do livro didático. Summus Ed. São Paulo.1984.

OOSTERHUIS, Harry. Medizin, Männerbund und die Homosexuelleverfolgung im Dritten Reich, p. 119126. In: JELLONNEK, Burkhard; LAUTMANN, Rüdiger (Hrsg.). Nationalsozialistischer Terror gegen Homosexuelle. Verdrängt und ungesühnt. Paderborn - München - Wien - Zürich: Ferdinand Schöningh Verlag, 2002.

PÖGGELER, Franz. Fremde und Fremheit im Schulbuch und der Wandel der Pädagogik. München: Opladen Verlag, 2004. 
PÖGGELER, Franz. Macht und Ohnmacht der Pädagogik. München: Opladen Verlag, 2003.

RODRIGUES, Raimundo Nina. As raças humanas e a responsabilidade penal no Brasil. Salvador: Livraria e Editora Progresso, 1957.

ROMERO, Sílvio. Prefácio a Tito Lívio da Costa (O Brasil e o Negro). Outlook. V. 106, p. 410, 21 fev, 2014, apud MUNANGA, Kabengele, Op. cit., p. 50.

REGINA, Cláudia de Paula, no livro Historias da Educação do Negro e Outras Historias,p,189. .

RÖNN, Peter von. Das Homosexualitätskonzept des Psychiaters Hans Bürger-Prinz im Rahmen der NSVerfolgunspolitik, 237-262. In: JELLONNEK, Burkhard; LAUTMANN, Rüdiger (Hrsg.). Nationalsozialistischer Terror gegen Homosexuelle. Verdrängt und ungesühnt. Paderborn - München Wien - Zürich: Ferdinand Schöningh Verlag, 2002.

ROSEMBERG, F. Literatura infantil e ideologia. São Paulo: Global, 1985.

SAVIANI, Dermeval. História das ideias pedagógicas no Brasil. $4^{\text {a }}$ Edição. Campinas, SP: Autores Associados, 2013 (Coleção memória da educação).

SCHÄFFTER, Ottfried (Hrsg.). Das Fremde. Erfahrungsmöglichkeiten zwischen Fazination und Bedrohung. Westdeutschland Verlag: Opladen 1991.

SCHMARCZ, Lilia Moritz. O espetáculo das raças. Cientistas, instituições e a questão racial no Brasil 1870-1930. 11ª impressão. São Paulo: Companhia das Letras, 1993.

SILVA, Paulo Vinícios Baptista da. Racismo em livros didáticos: estudo sobre negros e brancos em livros de língua portuguesa. Belo Horizonte: Autêntica editora, 2008 (Coleção Cultura Negra e Identidades).

TELLES, Edward. Racismo á brasileira: uma nova perspectiva sociológica. Rio de janeiro: Relume Dumará; Fundação fort,2003.

THOMPSON, John B. Ideologia e cultura moderna: teoria social crítica na era dos meios de comunicação de massa. Tradução do Grupo de Estudos sobre ideologia, comunicação e representações sociais da pósgraduação strictu sensu em Psicologia da PUCRS. Petrópolis: Vozes, 1995.

UNESCO. Educação Para Todos. História da educação do negro e outras histórias. 2005.

YOUSEFI, Hamid Reza / BROWN, Ina. Interkulturalität. Eine interdisziplinäre Einführung. Einführung Philosophie. Darmstadt: Wissen Bildung und Gemeinschaft Verlag/ WBG, 2012.

WOLLRAD, Eske. Weißsein im Widerspruch. Feministische Perspektiven auf Rassismus, Kultur und Religion. Königsstein/Taunus: Ulrike Helmer, 2005.

\section{Como citar este artigo (Formato ABNT):}

IFADIREÓ, Miguel Melo; SOUZA, Taís Oliveira de; ALBUQUERQUE, Érika de Sá Marinho; SOUSA, Maria do Socorro Cordeiro de. Educação Intercultural e suas Ambivalências com o Estranho. Um Estudo Sobre a Representação Social do Negro no Livro Didático. Id on Line Rev.Mult. Psic., 2019, vol.13, n.43, p. 1081-1104. ISSN: 1981-1179.

Recebido: 01/12/2018; Aceito: 03/12/2018. 